(Vol.VI, Maret 2015 )

\title{
HUBUNGAN TINGKAT PENGETAHUAN IBU HAMIL TENTANG RESIKO TINGGI KEHAMILAN DENGAN KETERATURAN ANTENATAL CARE (ANC) DI RB SOEGIARTI SURABAYA
}

\author{
Nyna Puspitaningrum \\ Tenaga Pengajar Prodi DIII Kebidanan, Universitas PGRI Adi Buana Surabaya
}

\begin{abstract}
ABSTRAK
Kehamilan merupakan proses yang alamiah, kehamilan didefinisikan sebagai fertilisasi atau penyatuan dari spermatozoa dan ovum dan dilanjutkan dengan nidasi atau implantasi. Kehamilan resiko tinggi merupakan suatu kehamilan dimana jiwa dan kesehatan ibu dan atau bayi dapat terancam. Antenatal Care (ANC) adalah pengawasan sebelum persalinan terutama ditujukan pada pertumbuhan dan perkembangan janin dalam rahim dan ibunya. Tujuan umum dari penelitian ini adalah untuk mengetahui hubungan pengetahuan ibu hamil tentang resiko tinggi kehamilan dengan keteraturan Antenatal Care (ANC). Desain penelitian bersifat analitik dengan pendekatan cross sectional dan dihitung menggunakan metode Chi Square. Sampel penelitian merupakan 30 ibu hamil trimester III yang melakukan Antenatal Care trimester III di RB Soegiarti Surabaya pada bulan Juni 2014. Setelah dilakukan uji analisa data dengan menggunakan metode Chi Square test, dengan berdasarkan $x^{2}$ tabel : 3,841 dan besaran $x^{2}$ hitung : 2,16; diperoleh hasil $x^{2}$ hitung $<x^{2}$ tabel. Berdasarkan penelitian ini jumlah responden yang teratur melakukan Antenatal Care (ANC) yakni 14 responden (46.67\%) dengan tingkat pengetahuan baik, 1 responden $(3.33 \%)$ dengan tingkat pengetahuan kurang. Sedangkan resonden yang tidak teratur melakukan Antenatal Care (ANC) sebanyak 11 responden (36.67\%) dengan tingkat pengetahuan baik dan 4 responden (13.33\%) dengan tingkat pengetahuan kurang. Maka dapat disimpulkan bahwa' "tidak ada hubungan antara tingkat pengetahuan ibu hamil resiko tinggi kehamilan dengan keteraturan Antenatal Care (ANC) di RB Soegiarti Surabaya". Dari hasil penelitian ini diharapkan kepada petugas kesehatan agar terus berupaya melaksanakan penyuluhan tentang resiko tinggi kehamilan dan akibat ketidakteraturan pemeriksaan Antenatal Care (ANC) terutama pada ibu hamil yang beresiko tinggi dengan menggunakan media yang mudah dimengerti oleh ibu hamil. Sedangkan bagi ibu hamil dianjurkan untuk meningkatkan pengetahuan, memperluas informasi tentang kesehatan ibu hamil dan kebutuhan gizi ibu hamil. Tetap melakukan pemeriksaan kehamilan secara rutin meskipun dalam kondisi normal serta menyertakan suami atau keluarga ibu hamil dalam kegiatan penyuluhan, sehingga tujuan kesehatan dapat tercapai.
\end{abstract}

Kata Kunci : Pengetahuan tentang resiko tinggi kehamilan, Keteraturan pemeriksaan Antenatal Care (ANC)

\section{PENDAHULUAN}

Tingginya angka kematian ibu (AKI) dapat menunjukkan masih rendahnya kualitas pelayanan kesehatan. Penurunan AKI juga merupakan indikator keberhasilan derajat kesehatan suatu wilayah. Pemerintah berupaya bahu membahu membuat berbagai strategi untuk akselerasi menurunkan AKI.
Program Kesehatan lbu dan Anak merupakan salah satu prioritas Kementerian Kesehatan dan keberhasilan program KIA menjadi salah satu indikator utama dalam Rencana Pembangunan Jangka Panjang Nasional (RPJPN) 2005 2025. Tingginya Angka Kematian Ibu (AKI) di Indonesia membuat pemerintah menempatkan upaya 
penurunan $\mathrm{AKI}$ sebagai program prioritas dalam pembangunan kesehatan.

Masalah kematian dan kesakitan ibu di Indonesia masih merupakan masalah besar. Angka Kematian Ibu (AKI) menurut SDKI (Survey Demografi Kesehatan Indonesia) tahun 2007, di Indonesia mencapai angka 248 per 100.000 kelahiran hidup dan Angka Kematian Bayi (AKB) sebesar 34 per 1.000 kelahiran hidup. AKI Di Propinsi Jawa Timur, pada tahun 2011 adalah 104.3 per 100.000 kelahiran hidup. Angka tersebut sudah melampaui dari target MDGs sebesar 102 per 100.000 kelahiran hidup, sedangkan AKB pada tahun 2011 adalah 29.24 per 1.000 kelahiran hidup, namun hal tersebut masih jauh dari target MDGs tahun 2015 yaitu sebesar 23 per 1.000 kelahiran hidup (http://dinkes.jatimprov.go.id).

WHO memperkirakan bahwa sekitar $15 \%$ dari seluruh wanita yang hamil akan mengalami komplikasi yang berkaitan dengan kehamilannya serta dapat mengancam jiwanya. Sebanyak 5.600.000 wanita hamil di Indonesia, sebagian besar akan mengalami suatu komplikasi atau masalah yang bisa menjadi fakta. Agar lebih efektif dalam meningkatkan keselamatan ibu dan bayi baru lahir, asuhan antenatal harus lebih difokuskan pada berbagai intervensi seperti pemberian edukasi dan peningkatan mutu pelayanan antenatal yang telah terbukti bermanfaat menurunkan angka kesakitan dan kematian ibu dan bayi baru lahir (Pusdiknakes-WHOJHPIEGO,2003).

Penyebab langsung kematian ibu terkait kehamilan dan persalinan terutama adalah perdarahan sebanyak $28 \%$. Penyebab lainnya seperti eklampsi $(24 \%)$, infeksi (11\%), partus lama (5\%), dan abortus (5\%). Angka kematian yang tinggi disebabkan 2 sebab pokok yaitu (1) masih kurangnya pengetahuan dan penanggulangan komplikasi penting dalam kehamilan, persalinan, serta nifás, (2) kurang meratanya pelayanan kebidanan yang baik bagi semua yang hamil (Wiknjosastro, 2005).

Faktor lain penyebab tingginya angka kematian ibu yang juga cukup penting seperti, latar belakang pendidikan, sosial ekonomi keluarga, lingkungan masyarakat, dan pandangan yang menganggap kehamilan adalah peristiwa alamiah sehingga ibu hamil dianggap tidak perlu untuk memeriksakan diri. Pandangan ini perlu diubah secara sosiokultural agar perempuan mendapat perhatian dari masyarakat. Sangat diperlukan upaya peningkatan pelayanan perawatan ibu baik oleh pemerintah, swasta, maupun masyarakat (Depkes, 2007). Berbagai upaya sangat diperlukan untuk menurunkan angka kematian ibu dan meningkatkan dukungan terhadap pelayanan dan kesehatan ibu/maternal, baik dalam antenatal care (ANC) dan meningkatkan cakupan persalinan oleh tenaga kesehatan.

Asuhan Antenatal menurut $\mathrm{MNH}$ (Maternal Neonatal Health) merupakan prosedur rutin yang dilakukan oleh petugas (dokter, bidan, perawat) dalam membina suatu hubungan dalam proses pelayanan ibu hamil untuk persiapan persalinannya yang harus dilakukan ibu hamil secara teratur. Sementara keteraturan ANC (Antenatal Care) sendiri adalah Kedisiplinan/kepatuhan ibu hamil untuk melakukan pengawasan sebelum anak lahir terutama ditujukan pada anak. Kunjungan antenatal care menurut WHO minimal empat kali dilakukan selama kehamilan yaitu Trimester $\mathrm{I}: 1 \mathrm{x}$, Trimester II:1x, dan Trimester III:2x. Hal itu ditujukan untuk mendeteksi dini jika terdapat resiko-resiko kehamilan supaya dapat teratasi segera. Program kunjungan antenatal dengan pelayanan / asuhan standar "14 T" 
yaitu: 1)Tanyakan dan menyapa ibu dengan ramah; 2)Tinggi badan dan berat badan di timbang; 3)Temukan kelainan/periksa daerah muka dan leher (gondok, vena jugularis externa), jari dan tungkai (edema), lingkaran lengan atas, panggul (perkusi ginjal) dan reflek lutut; 4)Tekanan darah diukur; 5)Tekan/paipasi payudara (benjolan), perawatan payudara, senam payudara, tekan titik (accu pressure) peningkatan ASl; 6)Tinggi fundus uteri diukur; 7)Tentukan posisi janin (Leopold I-IV) dan detak jantung janin; 8)Tentukan keadaan (palpasi) liver dan limpa; 9)Temukan kadar $\mathrm{Hb}$ dan periksa lab (protein dan glucosa urin), sediaan vagina dan VDRL (PMS) sesuai indikasi; 10)Terapi dan pencegahan anemia (tablet $\mathrm{Fe}$ ) dan penyakit lainnya sesuai indikasi (gondok, malaria, dll); 11)Tetanus toxoid imunisasi; 12)Tingkatkan kesegaran jasmani (accu pressure) dan senam hamil; 13)Tingkatkan pengetahuan ibu hamil (penyuluhan): makanan bergizi ibu hamil, tanda bahaya kehamilan, petunjuk agar tidak terjadi bahaya pada waktu kehamilan dan persalinan; 14) Temu wicara konseling.

Pemeriksaan ini bertujuan untuk memantau dan mengenali secara dini adanya ketidaknormalan atau komplikasi yang mungkin terjadi selama hamil. Setiap kehamilan dapat berkembang menjadi masalah atau komplikasi setiap saat, sehingga sangat diperlukan pemantauan selama kehamilan. Indikator yang digunakan untuk menggambarkan keberhasilan program pelayanan kesehatan ibu adalah cakupan pemeriksaan ibu hamil terhadap pelayanan kesehatan yang diukur dengan K1 dan K4. (Depkes $\mathrm{RI}, 2004)$. K1 adalah kunjungan ibu hamil yang pertama kali pada masa kehamilan, K1 dibagi menjadi dua yaitu $\mathrm{K} 1$ murni dan $\mathrm{K} 1$ akses. $\mathrm{K} 1$ murni adalah jumlah kontak pertama ibu hamil dengan tenaga kesehatan pada umur kehamilan kurang dari 12 minggu, sedangkan $\mathrm{K} 1$ akses adalah jumlah kontak pertama hamil dengan tenaga kesehatan melihat umur kehamilan. Cakupan K4 adalah gambaran besaran ibu hamil yang mendapatkan pelayanan ibu hamil sesuai standar serta paling sedikit empat kali kunjungan, dengan distribusi sekali pada trimestwer pertama, sekali pada trimester kedua, dan dua kali pada trimester ketiga. (Pedoman PWS KIA,2008).

Berdasarkan Survey Demografi dan Kesehatan di Indonesia pencapaian cakupan pemeriksaan kehamilan atau antenatal care (ANC) untuk pencapaian $\mathrm{K} 1$ tenaga kesehatan selama kehamilan yaitu sebesar 92,7\%, untuk pencapaian $\mathrm{K} 1$ tenaga kesehatan tribulan pertama sebesar $72,3 \%$. Dalam pendekatan registrasi kohort adalah yang dibenarkan mempunyai perbedaan $20,4 \%$ dengan $\mathrm{K} 1$ akses. Ini artinya bahwa $20,4 \%$ ibu-ibu hamil yang seharusnya tidak dicatat sebagai $\mathrm{K} 1$ yang diperiksa oleh tenaga kesehatan tribulan pertama telah dijadikan sebagai hasil cakupan. Untuk pencapaian $\mathrm{K} 4$ oleh tenaga kesehatan capaiannya adalah $61,4 \%$ (Ali, 2011).

Sedangkan di provinsi jawa timur gambaran presentasi cakupan pelayanan K4 Provinsi Jawa Timur tahun 2006 menurut table SPM 1, sebesar $564,616(81,79 \%)$ dari seluruh ibu hamil sebanyak 690.282 orang (Dinkes Jatim, 2009). Gambaran presentasi cakupan pelayanan $\mathrm{K} 4$ Kota Surabaya sebanyak $88,31 \%$ sedangkan target $\quad 91 \%$ (http://www.dinkes.go.id).

Berdasarkan data Kohort bulan januari 2013 di RB Soegiarti Surabaya, dari $33 \mathrm{~K} 1$ murni hanya $17 \mathrm{ibu}$ hamil yang mencapai K4 (52\%). Ini menunjukkan bahwa kesadaran ibu hamil dalam memeriksakan kehamilan masih relatif rendah. Seharusnya K4 terpenuhi $100 \%$ namun hanya $52 \%$. 
Oleh karena itu peneliti tertarik untuk melakukan penelitian tentang Hubungan Tingkat Pengetahuan Ibu Hamil Tentang Resiko Tinggi Kehamilan dengan Keteraruran Antenatal Care (ANC) di RB Soegiarti Surabaya.

\section{KAJIAN LITERATUR DAN PENGEMBANGAN HIPOTESIS}

Menurut Anwariansyah (2009) Pengetahuan didefinisikan bermacammacam, antara lain: 1) Keahlian dan keterampilan-keterampilan yang diperoleh oleh seseorang melalui pengalaman atau pendidikan, pemahaman praktis atau teoritis tentang suatu hal; 2) Apa yang dikenal di dalam bidang tertentu atau secara keseluruhan, baik fakta-fakta dan/atau informasinya; 3) Kesadaran atau keakraban yang diperoleh dari pengalaman melalui suatu fakta atau situasi.

Pengetahuan merupakan hasil "Tahu" dan ini terjadi setelah orang melakukan penginderaan terhadap suatu objek tertentu. Penginderaan terjadi melalui panca indera manusia, yakni: indera penglihatan, pendengaran, penciuman, rasa dan raba. Sebagian besar pengetahuan manusia diperoleh melalui mata dan telinga (Wajan dan Dewi, 2010). Dalam proses seseorang mengetahui akan dipengaruhi oleh beberapa hal atau faktor antara lain : 1) Usia; 2) Pendidikan; 3) Pengalaman.

Menurut Federasi Obstetri Ginekologi Internasional, kehamilan didefinisikan sebagai fertilisasi atau penyatuan dari spermatozoa dan ovum dan dilanjutkan dengan nidasi atau implantasi. Bila dihitung dari saat fertilisasi hingga lahirnya bayi, kehamilan normal akan berlangsung dalam waktu 40 minggu atau 10 bulan dan juga 9 bulan menurut kalender internasional. Kehamilan terbagi dalam 3 trimester. Dimana trimester kesatu berlangsung dalam 12 minggu, trimester kedua 15 minggu ( minggu ke-13 hingga ke-27) dan trimester ketiga 13 minggu (minggu ke-28 hingga ke-40) (Sarwono Prawirohardjo, 2009).

Setiap ibu hamil tentu menginginkan bisa menjalani kehamilannya dengan lancar. Selain perlu mengetahui hal-hal yang biasanya menyertai jalannya proses kehamilan, ibu hamil juga perlu mengenali beberapa tanda bahaya pada kehamilan supaya bisa segera mencari pertolongan medis. 9 tanda bahaya pada kehamilan yang perlu diketahui, adalah : 1) Mual dan muntah berlebihan (Hiperemesis gravidarum); 2) Kurang darah (anemia); 3) Berat badan ibu hamil tidak naik; 4) Nyeri kepala, gangguan penglihatan, kejang dan atau koma, tekanan darah tinggi; 5) Gerakan janin berkurang atau tidak ada; 6) Penyakit ibu yang berpengaruh terhadap kehamilan; 7) Ketuban Pecah Dini (KPD); 8) Perdarahan; 9) Demam tinggi. (Majalah Kesehatan Muslimah oleh dr. Avie Andriyani, 2011).

Kehamilan Resiko Tinggi (KRT) merupakan suatu kehamilan dimana jiwa dan kesehatan ibu dan atau bayi dapat terancam. Untuk menentukan suatu kehamilan resiko tinggi, dilakukan penilaian terhadap wanita hamil untuk menentukan apakah dia memiliki keadaan atau ciri-ciri yang menyebabkan dia atau janinnya lebih rentan terhadap penyakit atau kematian (keadaan atau ciri tersebut disebut faktor risiko) (Mochtar:201).

Jenis-Jenis Kehamilan Resiko Tinggi, yaitu : 1) $\mathrm{Hb}$ kurang dari $8 \mathrm{gr} \%$ (anemia); 2) Tekanan darah tinggi; 3) Eklamsia; 4) Perdarahan; 5) Ketuban Pecah Dini (KPD); 6) Letak lintang pada umur kehamilan lebih dari 32 minggu; 7) Letak Sungsang pada primigravida; 8) Infeksi berat atau sepsis; 9) Kehamilan ganda, janin yang besar; 10) Penyakit kronis pada ibu misalnya jantung, paru-paru, ginjal, dll; 11) Riwayat Obstetri buruk. 
Asuhan Antenatal adalah Upaya preventif program pelayanan kesehatan obstetrik untuk optimalisasi luaran maternal dan neonatal melalui serangkaian kegiatan pemantauan rutin selama kehamilan (Sarwono Prawirohardjo, 2009). Antenatal Care (ANC) adalah pengawasan sebelum persalinan terutama ditujukan pada pertumbuhan dan perkembangan janin dalam rahim dan ibunya (Manuaba, 2010).

Keteraturan

pelaksanaan antenatal care (ANC) ibu hamil dengan tenaga kesehatan adalah kunjungan yang dilakukan untuk memeriksakan kehamilannya (Depkes RI, 2010) sebagai berikut: 1). Trimester 1 kunjungan 1 kali; 2) Trimester II kunjungan 1 kali; 3) Trimester III kunjungan 2 kali.

\begin{tabular}{|c|c|c|c|}
\hline \multicolumn{4}{|c|}{ Jika pasien melakukan kunjungan Antenatal } \\
Care (ANC) pada:
\end{tabular}

Tabel 2.1 - Keteraturan Pelaksanaan Antenatal Care (ANC)

Faktor-faktor yang mempengaruhi keteraturan pelaksanaan ANC, yaitu : 1) Pengetahuan; 2) Sosial budaya; 3) Ekonomi; 4) Lingkungan; 5) Geografis. Sedangkan Faktor-faktor yang mempengaruhi perilaku, khususnya perilaku yang berhubungan dengan kesehatan, antara lain : (Notoatmodjo, 2003) Teori Lawrence Green (1980). Menurut Green, perilaku dipengaruhi oleh 3 faktor utama, yakni : 1) Faktor predisposisi (predisposing factor); 2) Faktor pemungkin (enabling factor); 3 ) Faktor penguat (reinforcing factor).

\section{METODE PENELITIAN}

Desain penelitian bersifat analitik karena metode penelitian yang dilakukan dengan tujuan utama menganalisa hubungan tingkat pengetahuan ibu hamil tentang resiko tinggi kehamilan dengan keteraturan antenatal care (ANC) dengan pendekatan cross sectional (Notoatmodjo, 2012). Populasi dalam penelitian ini adalah seluruh ibu hamil yang melakukan pemeriksaan kehamilan dan usia kehamilan masuk trimester III di RB Soegiarti Surabaya pada bulan Juni 2014.

Instrument yang digunakan pada penelitian ini adalah kuisioner dan buku KIA atau Register Kohort. Setelah data terkumpul maka akan dilakukan analisa data dan diuji dengan menggunakan Uji Chi Square.

$x^{2}=\sum \frac{(f o-f h)^{2}}{f h}$

Dimana, $x^{2}=$ chi kuadrat

fo $=$ frekuensi yang diperoleh berdasarkan data

$\mathrm{fh}=$ frekuensi yang diharapkan

\section{HASIL DAN PEMBAHASAN}

Data umum dalam penelitian ini berupa karakteristik ibu bersalin yang meliputi umur ibu, usia kehamilan, kehamilan yang keberapa, pendidikan terakhir, pekerjaan, pendapatan keluarga ibu hamil, dan sumber informasi. Dapat dilihat pada tabel sebagai berikut :

Tabel 4.1 Distribusi Responden Berdasarkan Umur lbu hamil trimester III di RB. Ny.Soegiarti Surabaya

\begin{tabular}{llll}
\hline No & Umur & $\mathbf{n}$ & $\%$ \\
\hline $\mathbf{1}$ & $<20$ tahun & 0 & 0.00 \\
$\mathbf{2}$ & $20-30$ tahun & 14 & 46.67 \\
$\mathbf{3}$ & $>30$ tahun & 16 & 53.33 \\
\hline Jumlah & & 30 & 100.00 \\
\hline
\end{tabular}

Pada penyajian tabel diatas menunjukkan bahwa berdasarkan umur responden, umur $<20$ tahun 
tidak ada (0\%). Responden berumur 20-30 tahun sebanyak 14 responden (46.67\%), dan responden umur $>30$ tahun sebanyak 16 responden $(53.33 \%)$.

Tabel 4.2 Distribusi Responden Berdasarkan Usia Kehamilan di RB. Ny.Soegiarti Surabaya

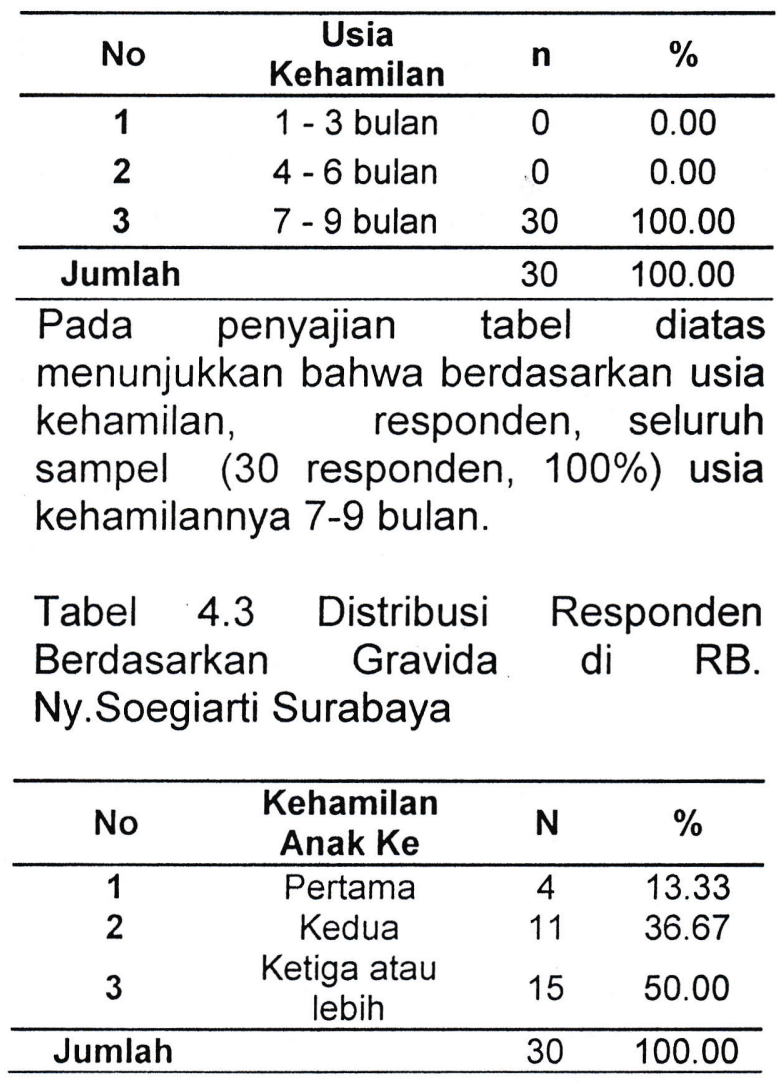

Berdasarkan tabel diatas responden yang hamil anak pertama sebanyak 4 responden (13.33\%), responden hamil anak kedua sebanyak 11 responden $(36.6 \%)$, sedangkan respon yang hamil anak ketiga atau lebih sebanyak 15 responden $(50.0 \%)$.

Tabel 4.4 Distribusi Responden Berdasarkan Pendidikan Terakhir ibu hamil trimester III di RB. Ny.soegiarti Surabaya

\begin{tabular}{cccc}
\hline No & Pendidikan & $\mathbf{N}$ & $\%$ \\
\hline $\mathbf{1}$ & SD / SMP & 12 & 40.00 \\
$\mathbf{2}$ & SMA & 16 & 53.33 \\
$\mathbf{3}$ & Akademi / PT & 2 & 6.67 \\
\hline Jumlah & & 30 & 100.00 \\
\hline
\end{tabular}

Tabel diatas menunjukkan responden dengan pendidikan SD/SMP sebanyak 12 responden (40.0\%), pendidikan SMA 16 responden (53.33\%), Akademi atau PT 2 responden (6.67\%).

Tabel 4.5 Distribusi Responden Berdasarkan Pekerjaan ibu hamil di RB.Ny.Soegiarti Surabaya

\begin{tabular}{|c|c|c|c|}
\hline No & Pekerjaan & $\mathbf{N}$ & $\%$ \\
\hline 1 & Tidak Bekerja & 13 & 43.33 \\
\hline 2 & $\begin{array}{c}\text { Swasta / } \\
\text { Wiraswasta }\end{array}$ & 17 & 56.67 \\
\hline 3 & PNS / TNI & 0 & 0.00 \\
\hline Jumlah & & 30 & 100.00 \\
\hline
\end{tabular}

Berdasarkan tabel diatas karakteristik responden berdasarkan pekerjaan, responden yang tidak bekerja 13 responden (13\%), Pegawai swasta/ Wiraswasta 17 responden (56.67\%), PNS atau TNI tidak ada (0\%).

Tabel 4.6 Distribusi Responden Berdasarkan pendapatan keluarga ibu hamil di RB.Ny.Soegiarti Surabaya

\begin{tabular}{cccc}
\hline No & $\begin{array}{c}\text { Pendapatan } \\
\text { Keluarga / Bulan }\end{array}$ & N & $\%$ \\
\hline $\mathbf{1}$ & $<$ Rp. 500.000,- & 0 & 0.00 \\
$\mathbf{2}$ & $\begin{array}{c}\text { Rp. 500.000,- } \\
\text { Rp. 1.000.000,- }\end{array}$ & 14 & 46.67 \\
$\mathbf{3}$ & $>$ Rp. 1.000.000,- & 16 & 53.33 \\
\hline Jumlah & & 30 & 100.00 \\
\hline
\end{tabular}

Berdasarkan tabel diatas karakteristik responden berdasarkan jumlah pendapatan, responden dengan pendapatan kurang dari Rp.500.000,- 
tidak ada, dengan pendapatan $\mathrm{Rp}$. 500.000,- - Rp. 1.000.000,- 14 responden (46.67\%), Lebih dari Rp. $1000.000,-16$ responden (53.33\%).

Tabel 4.7 Distribusi Responden Berdasarkan sumber informasi yang diperoleh ibu hamil di RB.Ny.Soegiarti Surabaya

\begin{tabular}{|c|c|c|c|}
\hline No & Sumber Informasi & $\mathbf{n}$ & $\%$ \\
\hline 1 & Petugas Kesehatan & 28 & 93.33 \\
\hline 2 & $\begin{array}{c}\text { Media Massa dan } \\
\text { Elektronik }\end{array}$ & 0 & 0.00 \\
\hline 3 & Keluarga / Tetangga & 2 & 6.67 \\
\hline Jumlah & & 30 & 100.00 \\
\hline
\end{tabular}

Tabel diatas menunjukkan berdasarkan sumber informasi yang diperoleh responden, 28 responden $(93.33 \%)$ dari petugas kesehatan, dari media massa dan elektronik tidak ada $(0 \%)$, dari keluarga/ tetangga 2 responden $(6.67 \%)$.

Berdasarkan tingkat pengetahuan tentang resiko tinggi kehamilan, responden diklasifikasikan dalam bentuk tabel sebagai berikut :

\begin{tabular}{cccc}
\hline No & $\begin{array}{c}\text { Tingkat Pengetahuan } \\
\text { Tentang Resiko Tinggi } \\
\text { Kehamilan }\end{array}$ & $\mathbf{n}$ & $\%$ \\
\hline $\mathbf{1}$ & Kurang (<10 poin $)$ & 5 & 16.67 \\
$\mathbf{2}$ & Baik ( > 10 poin $)$ & 25 & 83.33 \\
\hline Jumlah & & 30 & 100 \\
\hline
\end{tabular}

Tabel 4.8 Distribusi Responden
Berdasarkan Tingkat Pengetahuan Tentang Resiko Tinggi Kehamilan di RB.Ny.Soegiarti Surabaya

Responden dengan tingkat pengetahuan tentang resiko tinggi kehamilan kurang sebanyak 5 responden (16.67\%), dengan pengetahuan baik 25 responden (83.33\%).

Berdasarkan keteraturan antenatal care (ANC) pada responden diklasifikasikan dalam bentuk tabel sebagai berikut :

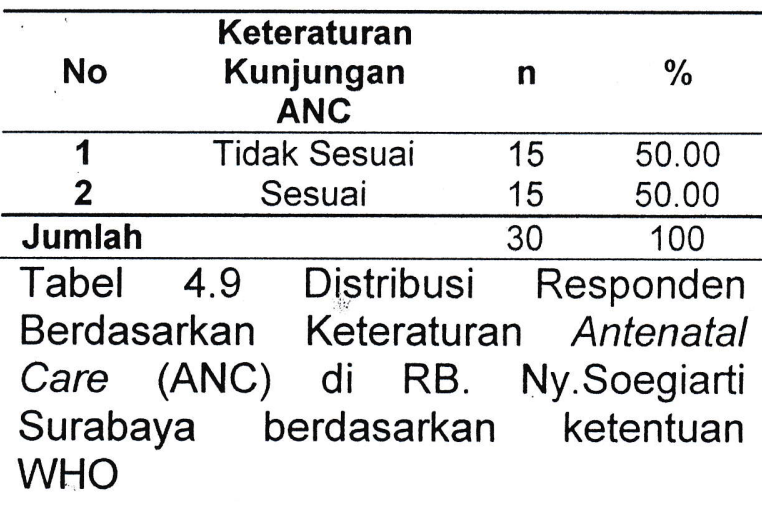

Berdasarkan keteraturan kunjungan Antenatal Care (ANC), responden tidak melakukan sesuai ketentuan WHO terdapat 11 responden (36.67\%), sesuai ketentuan WHO 19 responden (63.33\%). 
(Vol.VI, Maret 2015 )

\begin{tabular}{|c|c|c|c|c|c|c|c|}
\hline No & ngkat & Teratur & $\%$ & Tidak Teratur & $\%$ & Jumlah & $(\%)$ \\
\hline 1 & Baik & 14 & 46.67 & 11 & 36,67 & 25 & 83,34 \\
\hline \multirow[t]{2}{*}{2} & Kurang & 1 & 3,33 & 4 & 13,33 & 5 & 16,66 \\
\hline & Total & 15 & 50,00 & 15 & 50,00 & 30 & 100 \\
\hline
\end{tabular}

Tabel 4.10 Tabulasi Silang "Hubungan Tingkat Pengetahuan Ibu Hamil Tentang Resiko Tinggi Kehamilan dengan Keteraturan Antenatal Care(ANC)"

Berdasarkan tabel diatas, yang menunjukkan bahwa dari 30 responden dalam penelitian ini responden yang teratur melakukan Antenatal Care (ANC) yakni 14 responden (46.67\%) dengan tingkat pengetahuan baik, 1 responden (3.33\%) dengan tingkat pengetahuan kurang. Sedangkan resonden yang tidak teratur melakukan Antenatal Care (ANC) sebanyak 11 responden (36.67\%) dengan tingkat pengetahuan baik dan 4 responden (13.33\%) dengan tingkat pengetahuan kurang.

Setelah dilakukan uji statistik pada tabulasi silang diatas dengan menggunakan metode Chi-square test, dengan berdasarkan $x^{2}$ tabel : 3,841 dan besaran $x^{2}$ hitung : 2,16; maka $x^{2}$ hitung $2,16<x^{2}$ tabel 3.841. dengan demikian $\mathrm{H}_{0}$ diterima dan $\mathrm{H}_{1}$ ditolak yakni "tidak ada hubungan antara tingkat pengetahuan ibu hamil resiko tinggi kehamilan dengan keteraturan Antenatal Care (ANC) di RB Soegiarti Surabaya".

\section{KESIMPULAN}

Berdasarkan penelitian ini jumlah responden yang teratur melakukan Antenatal Care (ANC) yakni 14 responden $(46.67 \%)$ dengan tingkat pengetahuan baik, 1 responden $(3.33 \%)$ dengan tingkat pengetahuan kurang. Sedangkan resonden yang tidak teratur melakukan Antenatal Care (ANC) sebanyak 11 responden
(36.67\%) dengan tingkat pengetahuan baik dan 4 responden (13.33\%) dengan tingkat pengetahuan kurang. Maka dapat disimpulkan bahwa "tidak ada hubungan antara tingkat pengetahuan ibu hamil resiko tinggi kehamilan dengan keteraturan Antenatal Care (ANC) di RB Soegiarti Surabaya".

Dari hasil penelitian ini diharapkan kepada petugas kesehatan agar terus berupaya melaksanakan penyuluhan tentang resiko tinggi kehamilan dan akibat ketidakteraturan pemeriksaan Antenatal Care (ANC) terutama pada ibu hamil yang beresiko tinggi dengan menggunakan media yang mudah dimengerti oleh ibu hamil. Sedangkan bagi ibu hamil dianjurkan untuk meningkatkan pengetahuan, memperluas informasi tentang kesehatan ibu hamil dan kebutuhan gizi ibu hamil. Tetap melakukan pemeriksaan kehamilan secara rutin meskipun dalam kondisi normal serta menyertakan suami atau keluarga ibu hamil dalam kegiatan penyuluhan, sehingga tujuan kesehatan dapat tercapai.

Sesuai hasil penelitian dan pembahasan dapat disimpulkan : 1) Tingkat pengetahuan ibu hamil tentang resiko tinggi kehamilan di RB Soegiarti surabaya sebagian besar adalah baik. 25 responden (83.33\%); 2) Keteraturan Antenatalcare (ANC) di RB Soegiarti Surabaya sesuai dengan 
ketentuan WHO cukup yakni 15 responden (50.00\%); 3) Tidak ada hubungan pengetahuan ibu hamil tentang resiko tinggi kehamilan dengan keteraturan Antenatalcare (ANC) di RB Soegiarti Surabaya.

\section{REFERENSI}

Andriani, Avie. 2011. Majalah Kesehatan Muslimah. (htum Maialahkesehatenmushmah .com).

Arikunto, S. 2006. Prosedur Penelitian Suatu Pendekatan Praktek. Jakarta: Rineka Cipta.

Arikunto, S. 2009. Prosedur Penelitian Suatu Pendekatan Praktek. Jakarta: Rineka Cipta.

Cuwin/Hurlock. Pelayanan Kesehatan Maternal. Jakarta: Rineka Cipta.

Depkes RI, 2004. Pedoman Pelayanan Antenatal Tingkat Pelayanan Dasar Puskesmas. Jakarta: Pusdiknakes.

Depkes RI2010.Profilkesehatan Indonesia 2010. http://www.depkes.go.id. Diakses tanggal 20 Maret 2014 Pukul 23.30WIB

Erfandi, 2009. Asuhan Kebidanan Kehamilan Fisiologis. Jakarta: Salemba

Green,Lawrence., Kkreuter, Marshal, Deeds, sigrid.2000. Perencanaan Pendidikan Kesehatan Sebuah Pendekatan Diagnostik.Jakarta

Praktik Pelayanan Kesehatan Manuaba, IBG. 2010. IImu Kebidanan, Penyakit Kandungan dan Keluarga Berencana Untuk Pendidikan Bidan. Jakarta: EGC.
Mochtar Rustam, 2005. Sinopsis Obstetri III. Jakarta: EGC.

Notoatmodjo Soekidjo, 2012. Pendidikan dan Perilaku Kesehatan. Jakarta: Rineka Cipta.

Nursalam, 2003. Konsep dan Penerapan Metodologi Penelitian IImu Keperawatan: Pedoman Skripsi, Tesis dan Instrumen Penelitian Keperawatan. Jakarta: Salemba.

Saifuddin, Azwar. 2010. Buku Panduan Praktik Pelayanan Kesehatan Maternal dan Neonatal.Jakarta :PT Bina Pustaka Sarwono Prawirohardjo.

Santoso, Gempur. 2005. Metodelogi Penelitian Kuantitatif dan Kualitatif. Jakarta : Presentasi Pustaka

Sarwono, 2009. IImu Kebidanan. Jakarta: Yayasan Bina Pustaka.

Sugiyono, 2013. Statistik Untuk Penelitian. Bandung: Alfabeta.

Wayan dan Dewi, 2012. Asuhan Kebidanan Pada Kehamilan Fisiologis. Jakarta : Salemba Medika

Vivian Nanny dan Tri Sunarsih, 2011. Asuhan Kebidanan Pada Kehamilan Fisiologis. Jakarta : Salemba Medika

Kapita Selekta Kedokteran, 2010. IImu Kebidanan dan Kandungan. Jakarta : $\quad$ EGC 